\title{
An Investigation of Factors Affecting Brand Advertising Success and Effectiveness
}

\author{
Azarnoush Ansari ${ }^{1}$, Arash Riasi $^{2}$ \\ ${ }^{1}$ Department of Management, University of Isfahan, Isfahan, Iran \\ ${ }^{2}$ Institute for Financial Services Analytics, University of Delaware, Newark, DE, USA \\ Correspondence: Arash Riasi, Alfred Lerner College of Business \& Economics, Amstel Ave., Newark, DE, 19716, USA. \\ Tel: +1 (302) 898-6249. E-mail: riasi@udel.edu
}

\author{
Received: February 12, 2016 Accepted: February 23, $2016 \quad$ Online Published: March 5, 2016 \\ doi:10.5539/ibr.v9n4p20 \\ URL: http://dx.doi.org/10.5539/ibr.v9n4p20
}

\begin{abstract}
The purpose of this study is to identify the factors that affect advertising effectiveness and to investigate the effects of these factors on advertising success. Using a sample of 252 customers the study identified seven factors that affect brand advertising success and effectiveness, namely, advertising message and creativity, advertising media selection, market research, competitiveness, market share, uniqueness, and customer relationship. Path analysis and structural equation modelling (SEM) were used in order to test the proposed conceptual model of the study. The results revealed that advertising media selection has the strongest relationship with brand advertising success and effectiveness and can be considered as the most important factor affecting advertising effectiveness. The second and the third most important factors affecting advertising success were found to be advertising message/creativity and customer relationship. The results also indicated that although competitiveness impacts brand advertising success and effectiveness it is the least important factor among the seven factors identified in this study. Establishing appropriate relationships with customers and other stakeholders in order to understand their needs and demands is an important step toward improving the chances of brand advertising success and effectiveness. These relationships will also help the organizations to design their promotional campaigns according to the characteristics of their target customers which will contribute to the cumulative effectiveness of their brand advertisements.
\end{abstract}

Keywords: brand advertising, advertisement effectiveness, advertising success, brand image, advertising message, advertising media selection

\section{Introduction}

As a result of recent changes in people's life styles and the introduction of new products and services by various firms, disparate brands have been created by companies in order to better advertise their products/services to their target customers. Advertising is considered as the most popular form of communication that can be used in order to encourage consumers to purchase products/services (Hunag et al., 2012). An essential part of advertising is the creation and promotion of brands. Almost all organizations are engaged in some form of promotion (Jha et al., 2011) which means they are always looking for advertising agencies to publicize their brands and to introduce their new products/services by matching their advertising messages with their marketing strategies and their organizational goals. Nowadays, the way that the advertising message is delivered has become more important than the message itself (Fruchter et al., 2011). As a result of technological innovations, companies can now easily access their rivals' market data, which makes the business environment more competitive for all parties involved (Ansari and Riasi, 2016a, 2016b, 2016c). In an increasingly competitive marketplace, firms will try to use advertisements in order to improve their brand image (Meenaghan, 1995). Additionally, due to quick imitations, technological innovations no longer offer previous levels of sustainable competitive advantage (King, 1991; Meenaghan, 1995; Parker, 1991), therefore, the firms need to have strong brand images in order to be competitive for a relatively long time. Different advertising media with varying degrees of effectiveness and disparate levels of cost can be used to publicize the brands. However, enticing the customers to a particular brand is a difficult and time consuming task, mainly because many consumers do not pay attention to advertisements and often try to ignore them. Moreover, most advertisements are not intuitively understandable for consumers and as a result require that the receivers of the advertising message will be willing and able to allocate resources to cognitively process the contents of the advertisement (Bach Jensen and Lund Jepsen, 2007). Cognitive learning requires attention and if the target consumers are not attentive, then the firm should make an effort to 
understand how the prospective customers can learn about the company's brand (Bach Jensen and Lund Jepsen, 2007)

Iran is considered as one of the world's largest oil exporters and is also one of the largest exporters of agricultural products and fabric in the Middle East. Iranian companies have created various brands in recent years and have advertised their brands in both domestic and international markets. The recent economic and technological developments in Iran had a significant impact on the role of brands in this country. The goal of this study is to investigate the relationship between successful brand advertising and disparate factors including advertising message and creativity, advertising media selection, market research, competitiveness, market share, uniqueness, and customer relationship by focusing on the brands used by Iranian companies. This research contributes to the literature in this field mainly because it is the first study than investigates the factors affecting brand advertising in an emerging market economy.

\section{Conceptual Development}

\subsection{The Concept and Definition of Brand}

The American Marketing Association (AMA) (1960), defined brand as "a name, term, sign, symbol, or design, or a combination of them, intended to identify the goods or services of one seller or group of sellers and to differentiate them from those of competitors". This is one of the most widely accepted definitions of brand and many researchers have strictly adhered to it (e.g. Watkins, 1986; Aaker, 1991; Dibb et al, 1994; Kotler et al, 1996). Using an added value approach toward brand, De Chernatony and McDonald (1994) defined brand as "an identifiable product, service, person or place augmented in such a way that the buyer or user perceives relevant unique added values which match their needs more closely".

Brand can also be defined in the context of personality and psychological values (De Chernatony and Dall'Olmo Riley, 1998). Aaker (1996a) described brand personality as a metaphor which "can help brand strategists by enriching their understanding of people's perceptions and attitudes toward the brand, contributing to a differentiating brand identity, guiding the communication effort and creating brand equity". Using a consumer-based behavioral view of brand equity, Yoo and Donthu (2001) defined brand equity as "consumers' different response between a focal brand and an unbranded product when both have the same level of marketing stimuli and product attributes". According to Aaker (1991, 1996b), brand equity can be considered as a multidimensional concept which consists of brand loyalty, brand awareness, perceived quality, brand associations, and other proprietary brand assets.

\subsection{Perceived Brand Image}

Social and psychological studies on consumers revealed that individuals have the power to manage their emotions and brands rely on this ability to produce a good image in consumers' minds (Fennis and Pruyn, 2007; Fransen et al. 2008). Furthermore, the conceptual and emotional judgements of employees regarding their organizations are also based on their firms' brand value and their perceived brand image (Cardy et al., 2007). Employees attitude toward their organizations are affected by their experiences, beliefs, emotions, and the way outsiders talk about their organization. According to Martin et al. (2005), the way that internal and external stakeholders of an organization perceive the organizational personality can be shared using the same constructs. Therefore, an organization can be seen as trustworthy, enterprising, chic, competent, informal, or some combination of these types by customers, employees, and other stakeholders in a similar way (Martin et al., 2005). Aaker (1997) identified four major sources for brand value, namely, brand loyalty, brand awareness, perceived quality, and brand associations. Later, Keller (1998) combined these four sources of brand value into brand awareness and brand image. Keller (1993) defined brand image as "perceptions about a brand as reflected by the brand associations held in consumer memory". According to Keller (1993) these associations include perceptions of brand quality and attitudes toward the brand. Aaker (1991, 1996a) also proposed that brand associations are things that are linked to the brand in customers' memory. According to Keller (1993), the favorability, strength, and uniqueness of brand associations are three dimensions that distinguish brand knowledge and determine the differential response that makes up the brand equity. In fact, an important factor that determines the brand value is the customers' perceived brand image which is generated based on consumers' attitudes toward a specific brand (Michell et al., 2001). Previous research proved that brand image has a very specific impact on the consumers' perceptions of product/service quality while the firm's reputation has a stronger influence on perceptions of customer value and loyalty (Cretu and Brodie, 2007). Therefore, creating a positive brand image in consumers' memories using the core values of the firm and other distinguishing attributes of the company is one of the most salient priorities of every organization (Aaker, 1997). Low and Lamb Jr (2000), believe that brand image consists of both functional and symbolic brand beliefs. Brands play an important role in competitive markets where differentiating products/services is difficult (Cretu and Brodie, 2007; Riasi, 2015a, 2015b; Riasi and Amiri Aghdaie, 2013; Riasi and Pourmiri, 2015). Large companies who own the most renowned brands continuously try to reinforce their brand image by advertising and focusing on product/service differentiation. Nearly all firms spend large amounts of money for improving their brand 
image because they believe that stakeholders' attitude toward the company's brand is an important determinant of business success. A positive brand image helps the companies to recruit the most talented individuals (Saadat, 1996), find the best suppliers (Riasi, 2015a), and increase their market share (Kim and Chung, 1997). A company's brand image can be considered as the reflection of its objectives in employees' and customers' minds. When employees of an organization perceive a positive brand image they will have a sense of pride and loyalty and will work harder in order to pursue their organizational goals, and when consumers perceive a positive brand image they will increase their purchases and their loyalty levels will be augmented.

In order to better understand the factors affecting brand image it is necessary to investigate customers' attitudes and emotions. A customer's attitude toward a brand is formed during a learning process in which the consumer receives an advertising message from the firm and analyzes the message while considering his/her previous experiences. The advertising message and previous product/service experiences help the customer to create a brand image. The problem occurs when these two are not congruent; marketers should be able to remove these discrepancies (Mc Enally and De Chernatony, 1999). In order to have successful brand management, a firm should have an understanding of how the brand strategy is implemented and communicated to the customers and also how the customers respond to these strategies (Mc Enally and De Chernatony, 1999).

\subsection{Advertisement Effectiveness}

The American Marketing Association (AMA) (2016), defines advertisement as "any announcement or persuasive message placed in the mass media in paid or donated time or space by an identified individual, company, or organization". Beerli and Santana (1999) defined advertisement effectiveness as "the measurement of the results of an advertising campaign or of a particular advertisement, which must in turn be defined in terms of the achievement of the advertising objectives which the advertiser set for his campaign/advertisement". An advertisement is considered effective if it attracts the customer's attention, has a memorable impact on the customer, stimulate the customer's purchase intentions, and affect the customer's emotions (Adibi, 2012). According to Ramalingam et al. (2006), an effective advertisement has two main characteristics. First, advertiser should satisfy consumer's objectives by engaging the customer in the product/service experience and by delivering a relevant advertising message to the customer. Second, advertisements must be consistent with the objectives of the advertiser. Effective advertising has three broad dimensions, namely, strategy, creativity, and execution (Ramalingam et al., 2006). In order to have an effective advertisements, firms should connect these three elements (Ramalingam et al., 2006).

Sales volume and communication effects can be used to measure advertisement effectiveness. Although sales volume is affected by various factors which are not directly relevant to advertisement, including but not limited to pricing, packaging, and distribution quality, it is still considered as a suitable criterion for measuring advertisement effectiveness (Huang et al., 2011). Since communication effects are measurable, they can also be used as a benchmark for measuring advertisement effectiveness (Friedman and Friedman, 1979). Advertisement effectiveness have become a significant issue for many organizations as a result of limited monetary resources for advertisements, inconsistencies between customers' attitudes and their expectations, and highly competitive markets (Riasi, 2015b).

Reporting advertising expenses in financial reports as soon as they occur might be negatively perceived by companies' stakeholders. This is due to the fact that advertisement expenses may not lead to profits in short-term and they might affect the firm's profitability in future periods; therefore there is a high probability that profits due to advertising may not be reflected in the same financial reports as the ones which contain the advertisement expenses. In other words, when analyzing the financial reports, stakeholders are not usually able to compare the costs and benefits of advertisements. This indicates that measuring advertisement effectiveness is not an easy task and requires various skills which may not be available to all stakeholders.

\subsection{Measuring Advertisement Effectiveness}

Many scholars have studied advertisement effectiveness and different techniques which can be used for measuring advertisement effectiveness (e.g., Batra et al., 1995; Beerli and Santana, 1999; Danaher and Dagger, 2013; Gong and Maddox, 2003; Heerde et al., 2013; Korgaonkar et al., 1984; Lavidge and Steiner, 1961; Lewis and Reiley, 2014; Murphy and Maynard, 1996; Neal and Bathe, 1997). According to Neal and Bathe (1997), advertisement effectiveness can be judged either by examining whether the advertisement have led to an increase in the number of consumers who would consider the product/service or by investigating whether the promotional campaign improved the value of the product/service in the consumers' collective mind, thus increasing the number of customers who would choose the product/service. Neal and Bathe (1997) introduced the brand value model and the brand value equation in order to demonstrate how product/service attributes, brand equity, and price drive share of choice. Their study showed how measuring brand value can be used for testing advertisement effectiveness and how this measurement system can differentiate between changing a brand's perceived performance and changing how consumers view the entire category. 
Lavidge and Steiner (1961) categorized advertising effectiveness into global measurements and component measurements. They believe that global measurements are concerned with measuring the consumers' positions and movements on the purchase steps, whereas the component measurements are concerned with evaluating the relative effectiveness of various means of moving customers up the purchase steps. Gong and Maddox (2003), studied Chinese consumers' perceptions and responses to web banner advertising. In order to measure advertisement effectiveness they used brand awareness, attitude toward the advertisement, attitude toward the brand, and purchase considerations. Beerli and Santana (1999) used both cognitive and affective techniques in order to design a copy testing for measuring the effectiveness of advertisements placed in the daily press. They showed that the copy testing which they designed was valid, reliable, sensitive and independent in its applications and could as such be applied in similar promotional campaigns. Lewis and Reiley (2014) used click-through rate (CTR) in order to measure the effectiveness of online advertisements. Danaher and Dagger (2013) developed a method to help the companies examine the relative effectiveness of multiple advertising media. Particularly, they used a company's loyalty program database to capture media exposure for all the media in which the firm advertised. They matched the exposure data with the purchase history for the same respondents, and created single-source data. Batra et al. (1995) studied the effectiveness of advertising spending and found that trade promotion support is helpful in increasing advertisement effects on purchase intentions as long as the advertisement strategy is new, but not if the brand is mature and has a low quality. They used gross rating points (GRPs) in order to measure the effectiveness of advertising spending. Korgaonkar et al. (1984) found that competition among firms has an important impact on advertisement effectiveness. Their study indicated that as competition decreases the probability that an advertising campaign will be successful increases. Murphy and Maynard (1996) studied advertisement effectiveness by investigating the cognitive conflict between advertising agencies and their clients. They used multiple regression-based procedures in order to compare the decision profiles of advertising agency personnel and customers. By focusing on characteristics that both groups look for in an effective advertising campaign (i.e., market research, advertising budget, message/creativity, media planning and agency-client relationship.), they found that advertising agency personnel and their customers are quite similar in their judgments about the effectiveness of advertising campaigns, specifically on the issues of advertising budget and advertising message/creativity.

\subsection{Conceptual Model and Hypotheses}

In this study, the effects of seven different factors on brand advertising success and effectiveness are investigated. These factors include: advertising message and creativity, advertising media selection, market research, competitiveness, market share, uniqueness, and customer relationship.

Laskey et al. (1995) found that advertising message strategy has an impact on advertisement effectiveness. Furthermore, the findings of Murphy and Maynard (1996) indicated that clients consider advertising message and creativity as the most important factor in determining the quality of an advertisement campaign. Therefore, it is predicted that a well-designed and creative advertising message will have a positive impact on the success and effectiveness of brand advertising.

H1: Advertising message and creativity is positively related to brand advertising success and effectiveness.

The study by De Pelsmacker et al. (2002) revealed that advertisements shown in highly appreciated media result in a more positive attitude toward the advertisement. In other words, the choice of media for advertising a product/service has an impact on the overall success and effectiveness of the advertisement.

H2: Advertising media selection is positively related to brand advertising success and effectiveness.

Murphy and Maynard (1996) showed that market research is among the top three factors that clients typically look for in a good advertising campaign. Therefore, it is fair to posit that a strong market research will be interpreted as a positive attribute by customers and will lead to higher degrees of brand advertising effectiveness.

$\mathrm{H} 3$ : Market research is positively related to brand advertising success and effectiveness.

A study by Shaver and Lacy (1999) indicated that there is a negative relationship between competition among firms and the advertising success. This indicates that highly competitive firms are usually more successful in advertising (Amiri Aghdaie et al., 2012). These studies posit that a firm's degree of competitiveness has a positive impact on its brand advertising effectiveness.

H4: Competitiveness is positively related to brand advertising success and effectiveness.

Pollay et al. (1996) found a positive relationship between realized market share and advertising success. Therefore, it is fair to claim that the higher the market share of the firm the higher the chances of brand advertising effectiveness.

H5: Market share is positively related to brand advertising success and effectiveness. 
The study by Wells et al. (1971) showed that uniqueness is among the most important factors that customers use to evaluate the quality of television commercials. Therefore product/service uniqueness can lead to higher levels of perceived quality which in turn leads to an increase in the probability of advertising success and effectiveness.

H6: Uniqueness is positively related to brand advertising success and effectiveness.

Previous studies have shown that the advertisement effectiveness depends on the level of consumer involvement (Gordon et al., 1998). Particularly, when customer involvement is at a high level, the clients are very likely to devote more attention to advertisements, exert greater cognitive effort to comprehend the advertisements, focus their attention on information related to the product/service, and engage in more elaboration of product/service information in advertisements (Celsi and Olson, 1988; Gordon et al., 1998; Petty et al., 1983).

H7: Customer relationship is positively related to brand advertising success and effectiveness.

These seven hypotheses are summarized in figure 1 .

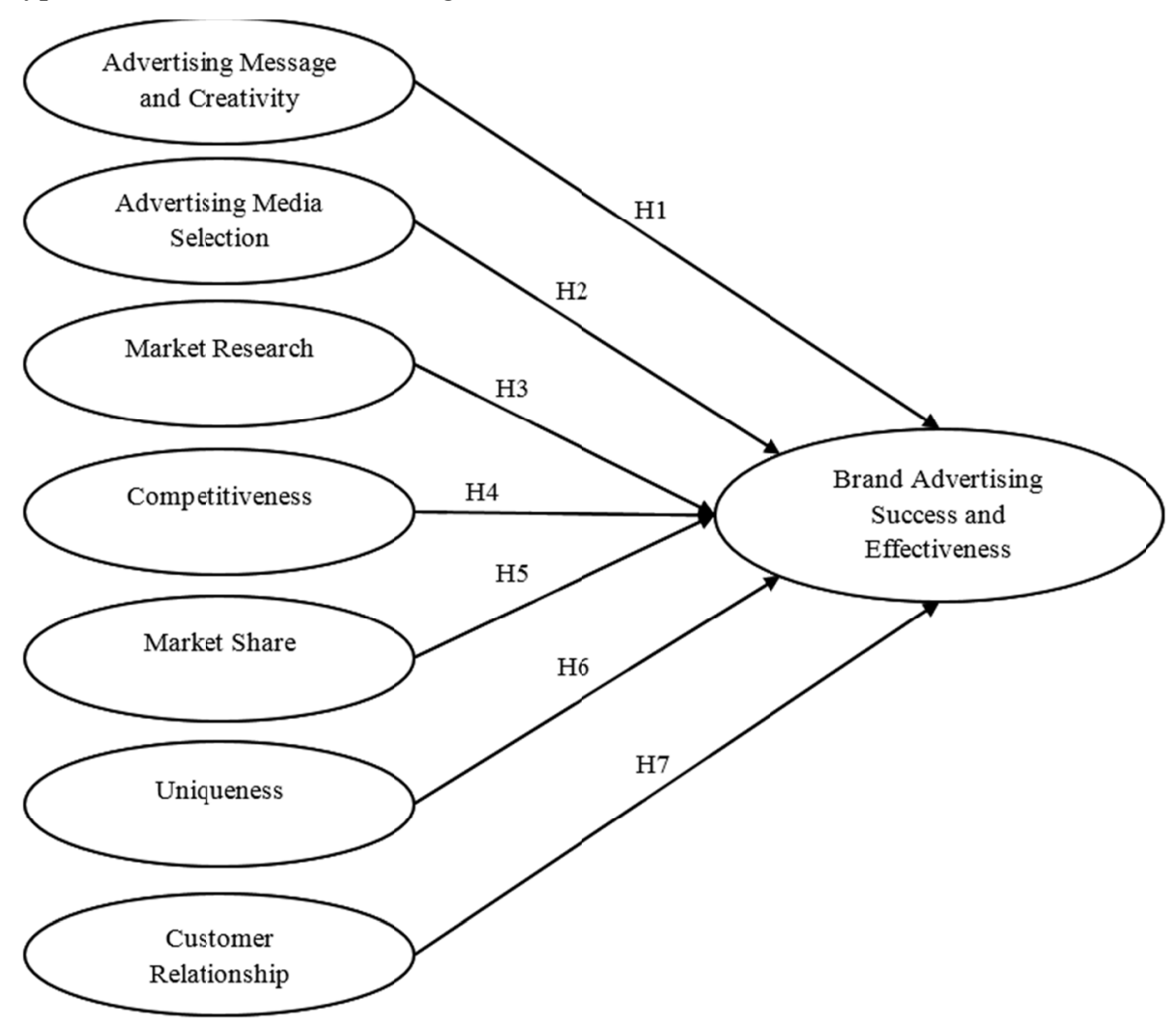

Figure 1. Conceptual model

\section{Methodology}

This study can be classified as an empirical research based on its objective and as a correlational research base on its methodology. By using Cochran's formula, a sample of 252 customers were selected to respond the surveys. All respondents were Iranian and were exposed to Iranian brands and their advertisements for a significant amount of time. The demographic characteristics of survey respondents are displayed in figure 2. 


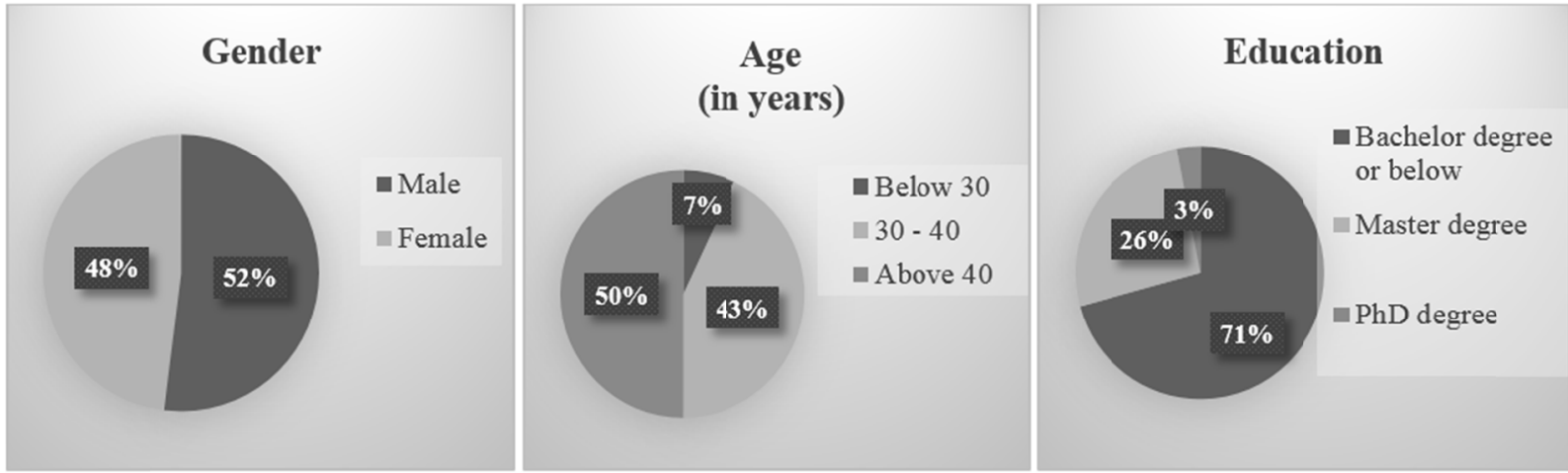

Figure 2. Demographic characteristics of survey respondents

In order to perform the data analysis, both descriptive and inferential statistical methods were used. IBM SPSS Statistics and IBM SPSS Amos were used to analyze the data and to perform the confirmatory factor analysis. The respondents were asked to rate the items in the survey on a seven-point Likert scale ranging from "completely disagree" (1) to "completely agree" (7), unless otherwise indicated. The content validity of the survey was approved by a group of five advertising agency managers and marketing professors. In order to test the reliability and internal consistency of the measures, Cronbach's alpha was calculated for each construct using IBM SPSS Statistics. The Cronbach's alphas for all scales were equal to or above 0.78 which exceeds the recommended 0.70 cutoff value (Nunnally \& Bernstein, 1994); indicating very high reliability and internal consistency of the scales.

In order to test the research hypotheses, path analysis was performed. Also to test the overall performance of the conceptual model, structural equation modeling (SEM) was used. Path analysis is a form of multiple regression that focuses on causality and is used in order to describe the directed dependencies among a set of variables. It can also be viewed as a special case of SEM, in which only single indicators are employed for each of the variables in the causal model. By using SEM, estimated paths can be tabulated and presented graphically as a path model, and the impact of variables can be assessed using path tracing rules. In order to evaluate model fit, different performance measures including root mean square error of approximation (RMSEA), goodness of fit index (GFI), adjusted goodness of fit index (AGFI), normed fit index (NFI), non-normed fit index (NNFI), parsimony normed fit index (PNFI), comparative fit index (CFI), and incremental fit index (IFI) were used in this study. The values of these measures and their recommended cutoff values are displayed in table 1. It can be seen that all performance measures exceeded their recommended cutoff values, which indicates that the data fitted the hypothesized measurement model. Confirmatory factor analysis revealed that all the scales which were designed for measuring advertising message and creativity, advertising media selection, market research, competitiveness, market share, uniqueness, customer relationship, and brand advertising success and effectiveness were acceptable.

Table 1. Performance measures for evaluating model fit

\begin{tabular}{ccccccccc}
\hline & GFI & AGFI & NNFI & NFI & CFI & IFI & PNFI & RMSEA \\
\hline $\begin{array}{c}\text { Conceptual } \\
\text { Model }\end{array}$ & 0.987 & 0.931 & 0.947 & 0.971 & 0.914 & 0.945 & 0.774 & 0.041 \\
\hline $\begin{array}{c}\text { Recommended } \\
\text { Cutoff Values }\end{array}$ & $>0.9$ & $>0.9$ & $>0.9$ & $>0.9$ & $>0.9$ & $>0.9$ & $>0.5$ & $<0.1$ \\
\hline
\end{tabular}

\section{Results}

After evaluating the model fit, the research hypotheses were tested by using path analysis. In order to approve or reject the research hypotheses, p-value and critical ratio were used. Critical ratio is calculated by dividing the regression weight estimate by the estimate of its standard error. If the critical ratio is larger than 1.96 for a regression weight, then that path is significant at the 0.05 level or in other words the estimated path parameter is significant. Additionally p-values smaller than 0.05 indicate a significant difference between the calculated regression weights and zero at 95 percent confidence level. The results of hypotheses test are as follows:

H1 posits that advertising message and creativity is positively related to brand advertising success and effectiveness. The results of path analysis revealed that the standardized regression coefficient for this relationship is 0.72 . Since the p-value was below 0.05 and the critical ratio was above 1.96, hypothesis $\mathrm{H} 1$ was supported with 95 percent confidence, indicating that advertising message and creativity is significantly associated with brand advertising effectiveness.

$\mathrm{H} 2$ posits that advertising media selection is positively related to brand advertising success and effectiveness. The 
results of path analysis showed that the standardized regression coefficient for this relationship is 0.93 . Since the p-value was below 0.05 and the critical ratio was above 1.96, hypothesis $\mathrm{H} 2$ was supported with 95 percent confidence, indicating that advertising media selection is significantly associated with brand advertising effectiveness.

H3 posits that market research is positively related to brand advertising success and effectiveness. The results of path analysis indicated that the standardized regression coefficient for this relationship is 0.60 . Since the p-value was below 0.05 and the critical ratio was above 1.96, hypothesis $\mathrm{H} 3$ was supported with 95 percent confidence, indicating that market research is significantly associated with brand advertising effectiveness.

$\mathrm{H} 4$ posits that competitiveness is positively related to brand advertising success and effectiveness. The results of path analysis revealed that the standardized regression coefficient for this relationship is 0.34 . Since the p-value was below 0.05 and the critical ratio was above 1.96, hypothesis $\mathrm{H} 4$ was supported with 95 percent confidence, indicating that competitiveness is significantly associated with brand advertising effectiveness.

H5 posits that market share is positively related to brand advertising success and effectiveness. The results of path analysis showed that the standardized regression coefficient for this relationship is 0.66 . Since the p-value was below 0.05 and the critical ratio was above 1.96, hypothesis H5 was supported with 95 percent confidence, indicating that market share is significantly associated with brand advertising effectiveness.

H6 posits that uniqueness is positively related to brand advertising success and effectiveness. The results of path analysis indicated that the standardized regression coefficient for this relationship is 0.62 . Since the p-value was below 0.05 and the critical ratio was above 1.96, hypothesis H6 was supported with 95 percent confidence, indicating that uniqueness is significantly associated with brand advertising effectiveness.

$\mathrm{H} 7$ posits that customer relationship is positively related to brand advertising success and effectiveness. The results of path analysis revealed that the standardized regression coefficient for this relationship is 0.70 . Since the p-value was below 0.05 and the critical ratio was above 1.96, hypothesis $\mathrm{H} 7$ was supported with 95 percent confidence, indicating that customer relationship is significantly associated with brand advertising effectiveness.

Table 2 summarizes these results and displays the regression coefficient, p-value, and critical ratio for each path.

Table 2. Results of hypotheses testing

\begin{tabular}{lcccc}
\hline \multicolumn{1}{c}{ Hypotheses } & $\begin{array}{c}\text { Regression } \\
\text { Coefficient }\end{array}$ & $\begin{array}{c}\text { Critical } \\
\text { Ratio }\end{array}$ & P-Value & Decision \\
\hline $\begin{array}{l}\text { H1: Advertising message and creativity is positively } \\
\text { related to brand advertising success and effectiveness. }\end{array}$ & 0.72 & 4.89 & $<0.01$ & H1 is supported \\
\hline $\begin{array}{l}\text { H2: Advertising media selection is positively related to } \\
\text { brand advertising success and effectiveness. }\end{array}$ & 0.93 & 5.80 & $<0.01$ & H2 is supported \\
\hline $\begin{array}{l}\text { H3: Market research is positively related to brand } \\
\text { advertising success and effectiveness. }\end{array}$ & 0.60 & 4.75 & $<0.01$ & H3 is supported \\
\hline $\begin{array}{l}\text { H4: Competitiveness is positively related to brand } \\
\text { advertising success and effectiveness. }\end{array}$ & 0.34 & 3.94 & $<0.01$ & H4 is supported \\
\hline $\begin{array}{l}\text { H5: Market share is positively related to brand advertising } \\
\text { success and effectiveness }\end{array}$ & 0.66 & 4.45 & 0.02 & H5 is supported \\
\hline $\begin{array}{l}\text { H6: Uniqueness is positively related to brand advertising } \\
\text { success and effectiveness. }\end{array}$ & 0.62 & 4.69 & 0.03 & H6 is supported \\
\hline $\begin{array}{l}\text { H7: Customer relationship is positively related to brand } \\
\text { advertising success and effectiveness. }\end{array}$ & 0.70 & 4.84 & $<0.01$ & H7 is supported \\
\hline
\end{tabular}

\section{Discussion}

With new technological advances, new brands emerge on a daily basis. Every day, customers observe new products/services under different brands that strive for capturing a larger market share in today's competitive business environment. Advertising agencies use their creativity and strategic advertising planning in order to help these new brands to succeed in the extremely competitive business environment. Their ultimate goal is to augment the level of consumer loyalty by building a positive brand image in customers' minds. This study clearly contributes to the existing literature in this field by identifying different factors that affect brand advertising success and effectiveness and investigating the relationship between each of these factors and advertising effectiveness. The list of factors affecting advertising success and effectiveness which was identified and investigated in this study covers various marketing 
concepts including advertising message and creativity, advertising media selection, market research, competitiveness, market share, uniqueness, and customer relationship. The other contribution of this research is that it is the first study to investigate factors affecting brand effectiveness in an emerging market economy. Particularly, the sample of this study included Iranian consumers which have been exposed to a large number of recently emerged brands in their country.

This study tested the effects of seven different factors that affect brand advertising success and effectiveness. The results indicated that a strong and creative advertising message will increase the probability of brand advertising effectiveness. This finding is consistent with Laskey et al. (1995) and Murphy and Maynard (1996) who found that a creative advertisement and a well-designed advertising message contribute to the positive brand image of the firm. A well-designed advertising message is one that describes the advertised product/service with charming expressions that are based on its actual attributes. Consistent with the study by De Pelsmacker et al. (2002), the findings of this research showed that an insightful selection of advertising media can help an organization to succeed in its brand advertising. Insightful selection of advertising media means that the company should carefully examine all possible advertising media in which it can advertise its products/services, and then perform a cost-benefit analysis (CBA) to find out which advertising media will help the company to generate more revenue and are more congruent with the company's marketing objectives, advertising budget, target audience, and production capacity. The results also revealed that appropriate market research helps the firms to augment their chances of brand advertising success and effectiveness. In other words, effective brand advertising is achieved not only by collecting a significant amount of data from customers, suppliers, and other market participants but also by analyzing these data using state of the art data analytics tools and interpreting the results by using marketing experts. Findings indicated that a company with competitive advantage over its rivals and a large market share has a higher chance of being successful in its brand advertising. Generally, a company that has a significant competitive advantage and a large market share is known by a larger group of customers compared to a company without a significant competitive advantage and with a relatively small market share, therefore the former can expect a more favorable response from the customers when introducing a new product/service or when advertising its brand. The results showed that product/service uniqueness contributes to advertisement effectiveness. Customers are willing to experience new products/services with unique features, specifically those products which offer some sort of technological innovation. Therefore, advertisements of unique products/services have a high chance of success because they respond to consumers' desire for innovative products/services. Finally, the findings revealed that an appropriate relationship between customers and producers or service providers can enhance the brand advertising effectiveness. An appropriate customer relationship means high levels of consumer involvement, fair treatment of customers, friendly relationship with consumers, offering high quality products/services, and improving customer satisfaction. It is clear that if customers experience a good relationship with their providers, they will have a positive attitude toward the firm and its brand, thus the chances of advertising success and effectiveness will be intensified.

\section{Conclusions and Managerial Implications}

The results of this study accentuate the importance of properly communicating with consumers in order to prosper in competitive business environments. Integrated marketing communication (IMC) which is an approach toward achieving the objectives of a marketing campaign, through well-coordinated use of promotional methods and communication disciplines is the key asset of every organization. Advertising is one of the most salient forms of communication, therefore identifying and investigating the factors that affect advertising success and effectiveness can help the firms to use their limited resources more efficiently and to improve their brand image. This study identified seven different factors that significantly affect brand advertising success and effectiveness. The results revealed that advertising media selection has the strongest relationship with brand advertising success and effectiveness and can be considered as the most important factor affecting advertising effectiveness. The second and the third most important factors affecting advertising success were found to be advertising message/creativity and customer relationship. The results also indicated that although competitiveness impacts brand advertising success and effectiveness it is the least important factor among the seven factors identified in this study. Based on the results of this study the following managerial implications are provided:

- In order to have an effective customer-oriented brand advertising strategy, companies should offer high quality products/services, should try to augment customer value added (CVA), and should focus on offering unique and innovative products/services.

- Managers should always be aware of the technological advances and changes in consumers' preferences when designing their brand advertising strategies, because these two factors can significantly affect the firms' market share, product/service uniqueness, and competitiveness which in turn affect brand advertising success and effectiveness. 
- Establishing appropriate relationships with customers and other stakeholders in order to understand their needs and demands is an important step toward improving the chances of brand advertising success and effectiveness. These relationships will also help the organizations to create their advertisement campaigns according to the characteristics of their target customers which will contribute to the effectiveness of their brand advertisements.

- Supporting the innovative and creative ideas for brand advertising and allocating financial and non-financial resources to pursue these ideas will be beneficial for the company in the long-term and will help the firm to reduce its costs, increase the revenues, and most importantly enhance the effectiveness of the promotional campaigns.

\section{References}

Aaker, D. A. (1991). Managing Brand Equity. New York, NY: The Free Press.

Aaker, D. A. (1996a). Building Strong Brands, New York, NY: The Free Press.

Aaker, D. A. (1996b). Measuring brand equity across products and markets. California Management Review, 38(3), 102-120. http://dx.doi.org/10.2307/41165845

Aaker, J. L. (1997). Dimensions of brand personality. Journal of Marketing Research, 34(3), $347-356$. http://dx.doi.org/10.2307/3151897

Adibi, R. (2012). Signs of semantics: three questions about visual meaning. Tehran, Iran: SAMT Publication.

American Marketing Association (1960). Marketing Definitions: A Glossary of Marketing Terms, Chicago, IL: American Marketing Association.

American Marketing Association (2016). Dictionary. Retrieved February 1, 2016, from https://www.ama.org/resources/Pages/Dictionary.aspx

Amiri Aghdaie, S. F., Seidi, M., \& Riasi, A. (2012). Identifying the Barriers to Iran's Saffron Export by Using Porter's Diamond Model. International Journal of Marketing Studies, 4(5), 129-138. http://dx.doi.org/10.5539/ijms.v4n5p129

Ansari, A., \& Riasi, A. (2016a). Analyzing the Customers' Shopping Location Preferences by Using Decision Trees. Working Paper.

Ansari, A., \& Riasi, A. (2016b). Clustering the Customers of Steel Industry Using a Combination of Fuzzy C-Means and Genetic Algorithms. Working Paper.

Ansari, A., \& Riasi, A. (2016c). Modelling and Evaluating Customer Loyalty Using Neural Networks: Evidence from Startup Insurance Companies. Working Paper.

Bach, J. M., \& Lund, J. A. (2007). Low attention advertising processing in B2B markets. Journal of Business \& Industrial Marketing, 22(5), 342-348. http://dx.doi.org/10.1108/08858620710773477

Batra, R., Lehmann, D. R., Burke, J., \& Pae, J. (1995). When does advertising have an impact? A study of tracking data. Journal of Advertising Research, 35(5), 19-33.

Beerli, A., \& Santana, J. D. M. (1999). Design and validation of an instrument for measuring advertising effectiveness in the printed media. Journal of Current Issues \& Research in Advertising, 21(2), 11-30. http://dx.doi.org/10.1080/10641734.1999.10505092

Cardy, R. L., Miller, J. S., \& Ellis, A. D. (2007). Employee equity: Toward a person-based approach to HRM. Human Resource Management Review, 17(2), 140-151. http://dx.doi.org/10.1016/j.hrmr.2007.03.006

Celsi, R. L., \& Olson, J. C. (1988). The role of involvement in attention and comprehension processes. Journal of Consumer Research, 15(2), 210-224.

Cretu, A. E., \& Brodie, R. J. (2007). The influence of brand image and company reputation where manufacturers market to small firms: A customer value perspective. Industrial Marketing Management, 36(2), $230-240$. http://dx.doi.org/10.1016/j.indmarman.2005.08.013

Danaher, P. J., \& Dagger, T. S. (2013). Comparing the relative effectiveness of advertising channels: A case study of a multimedia blitz campaign. Journal of Marketing Research, 50(4), 517-534. http://dx.doi.org/10.1509/jmr.12.0241

De Chernatony, L., \& Dall'Olmo Riley, F. (1998). Defining a brand: Beyond the literature with experts' interpretations. Journal of Marketing Management, 14(5), 417-443.

http://dx.doi.org/10.1362/026725798784867798 
De Chernatony, L., \& McDonald, M. (1994). Creating powerful brands. Oxford, United Kingdom: Butterworth-Heinemann.

De Pelsmacker, P., Geuens, M., \& Anckaert, P. (2002). Media context and advertising effectiveness: The role of context appreciation and context/ad similarity. Journal of Advertising, 31(2), 49-61. http://dx.doi.org/10.1080/00913367.2002.10673666

Dibb, S., Simkin, L., Pride, W. M., \& Ferrell, O. C. (1994). Marketing. Boston, MA: Houghton Mifflin.

Fennis, B. M., \& Pruyn, A. T. H. (2007). You are what you wear: Brand personality influences on consumer impression formation. Journal of Business Research, 60(6), 634-639. http://dx.doi.org/10.1016/j.jbusres.2006.06.013

Fransen, M. L., Fennis, B. M., Pruyn, A. T. H., \& Das, E. (2008). Rest in peace? Brand-induced mortality salience and consumer behavior. Journal of Business Research, 61(10), 1053-1061. http://dx.doi.org/10.1016/j.jbusres.2007.09.020

Friedman, H. H., \& Friedman, L. (1979). Endorser effectiveness by product type. Journal of Advertising Research, 19(5), 63-71.

Fruchter, G. E., \& Van den Bulte, C. (2011). Why the Generalized Bass Model leads to odd optimal advertising policies. International Journal of Research in Marketing, 28(3), 218-230. http://dx.doi.org/10.1016/j.ijresmar.2011.03.005

Gong, W., \& Maddox, L. M. (2003). Measuring web advertising effectiveness in China. Journal of Advertising Research, 43(01), 34-49. DOI: 10.1017/S002184990303006X

Gordon, M. E., McKeage, K., \& Fox, M. A. (1998). Relationship marketing effectiveness: the role of involvement. Psychology and Marketing, 15(5), 443-459.

Heerde, H. J. V., Gijsenberg, M. J., Dekimpe, M. G., \& Steenkamp, J. B. E. (2013). Price and advertising effectiveness over the business cycle. Journal of Marketing Research, 50(2), 177-193. http://dx.doi.org/10.1509/jmr.10.0414

Huang, J., Leng, M., \& Liang, L. (2012). Recent developments in dynamic advertising research. European Journal of Operational Research, 220(3), 591-609. http://dx.doi.org/10.1016/j.ejor.2012.02.031

Huang, W. S., Hsieh, T., \& Chen, H. S. (2011). The advertisement effectiveness of animated spokes-characters. African journal of business management, 5(23), 9971-9978.

Jha, P. C., Aggarwal, R., \& Gupta, A. (2011). Optimal media planning for multi-products in segmented market. Applied Mathematics and Computation, 217(16), 6802-6818. http://dx.doi.org/10.1016/j.amc.2010.12.111

Keller, K. L. (1993). Conceptualizing, measuring, and managing customer-based brand equity. The Journal of Marketing, 57(1), 1-22. http://dx.doi.org/10.2307/1252054

Keller, K. L. (1998). Strategic Brand Management: Building, Measuring, and Managing Brand Equity. Upper Saddle River, NJ: Prentice Hall.

Kim, C. K., \& Chung, J. Y. (1997). Brand popularity, country image and market share: an empirical study. Journal of International Business Studies, 28(2), 361-386.

King, S. (1991). Brand building in the 1990s. Journal of Consumer Marketing, 8(4), 43-52. http://dx.doi.org/10.1108/07363769110035144

Korgaonkar, P. K., Moschis, G. P., \& Bellenger, D. N. (1984). Correlates of successful advertising campaigns. Journal of Advertising Research, 24(1), 47-53.

Kotler, P., Armstrong, G., Saunders, J., \& Wong, V. (1996). Principles of Marketing. London, United Kingdom: Prentice Hall Europe.

Laskey, H. A., Fox, R. J., \& Crask, M. R. (1995). The relationship between advertising message strategy and television commercial effectiveness. Journal of Advertising Research, 35(2), 31-40.

Lavidge, R. J., \& Steiner, G. A. (1961). A model for predictive measurements of advertising effectiveness. Journal of Marketing, 25(10), 59-62

Lewis, R. A., \& Reiley, D. H. (2014). Online ads and offline sales: measuring the effect of retail advertising via a controlled experiment on Yahoo! Quantitative Marketing and Economics, 12(3), 235-266. http://dx.doi.org/10.1007/s11129-014-9146-6

Low, G. S., \& Lamb Jr, C. W. (2000). The measurement and dimensionality of brand associations. Journal of Product \& Brand Management, 9(6), 350-370. http://dx.doi.org/10.1108/10610420010356966 
Martin, G., Beaumont, P., Doig, R., \& Pate, J. (2005). Branding: A New Performance Discourse for HR? European Management Journal, 23(1), 76-88. http://dx.doi.org/10.1016/j.emj.2004.12.011

McEnally, M. R., \& De Chernatony, L. (1999). The evolving nature of branding: consumer and managerial considerations. Academy of Marketing Science Review, 99(2), 1-26.

Meenaghan, T. (1995). The role of advertising in brand image development.Journal of Product \& Brand Management, 4(4), 23-34. http://dx.doi.org/10.1108/10610429510097672

Michell, P., King, J., \& Reast, J. (2001). Brand values related to industrial products. Industrial Marketing Management, 30(5), 415-425. http://dx.doi.org/10.1016/S0019-8501(99)00097-8

Murphy, P., \& Maynard, M. L. (1996). Using judgment profiles to compare advertising agencies' and clients' campaign values. Journal of Advertising Research, 36(2), 19-28.

Neal, W. D., \& Bathe, S. (1997). Using the value equation to evaluate campaign effectiveness. Journal of Advertising Research, 37(3), 80-86.

Nunnally, J. C., \& Bernstein, I. H. (1994). Psychometric theory (3 ${ }^{\text {rd }}$ Ed.). New York: McGraw-Hill.

Parker, K. (1991). Sponsorship: The research contribution. European Journal of Marketing, 25(11), 22-30. http://dx.doi.org/10.1108/EUM0000000000629

Petty, R. E., Cacioppo, J. T., \& Schumann, D. (1983). Central and peripheral routes to advertising effectiveness: The moderating role of involvement. Journal of Consumer Research, 10(2), 135-146.

Pollay, R. W., Siddarth, S., Siegel, M., Haddix, A., Merritt, R. K., Giovino, G. A., \& Eriksen, M. P. (1996). The last straw? Cigarette advertising and realized market shares among youths and adults, 1979-1993. The Journal of Marketing, 60(2), 1-16. http://dx.doi.org/10.2307/1251927

Ramalingam, V., Palaniappan, B., Panchanatham, N., \& Palanivel, S. (2006). Measuring advertisement effectiveness - a neural network approach. Expert Systems with Applications, 31(1), 159-163. http://dx.doi.org/10.1016/j.eswa.2005.09.014

Riasi, A. (2015a). Barriers to international supply chain management in Iranian flower industry. Management Science Letters, 5(4), 363-368. http://dx.doi.org/10.5267/j.msl.2015.2.005

Riasi, A. (2015b). Competitive Advantages of Shadow Banking Industry: An Analysis Using Porter Diamond Model. Business Management and Strategy, 6(2), 15-27. http://dx.doi.org/10.5296/bms.v6i2.8334

Riasi, A., \& Amiri Aghdaie, S. F. (2013). Effects of a Hypothetical Iranian Accession to the World Trade Organization on Iran's Flower Industry. Consilience: The Journal of Sustainable Development, 10(1), 99-110. http://dx.doi.org/10.7916/D8HQ3ZK8

Riasi, A., \& Pourmiri, S. (2015). Effects of online marketing on Iranian ecotourism industry: Economic, sociological, and cultural aspects. Management Science Letters, 5(10), 915-926. http://dx.doi.org/10.5267/j.msl.2015.8.005

Saadat, E. (1996). Human Resources Management. Tehran, Iran: SAMT Publication

Shaver, M. A., \& Lacy, S. (1999). The impact of intermedia and newspaper competition on advertising linage in daily newspapers. Journalism \& Mass Communication Quarterly, 76(4), 729-744. http://dx.doi.org/10.1177/107769909907600409

Watkins, T. (1986). The economics of the brand. Maidenhead, United Kingdom: McGraw Hill Book Company.

Wells, W. D., Leavitt, C., \& McConville, M. (1971). A reaction profile for TV commercials. Journal of Advertising Research, 11(6), 11-18.

Yoo, B., \& Donthu, N. (2001). Developing and validating a multidimensional consumer-based brand equity scale. Journal of Business Research, 52(1), 1-14. http://dx.doi.org/10.1016/S0148-2963(99)00098-3

\section{Copyrights}

Copyright for this article is retained by the author(s), with first publication rights granted to the journal.

This is an open-access article distributed under the terms and conditions of the Creative Commons Attribution license (http://creativecommons.org/licenses/by/3.0/). 